\title{
One Factor at A Time based optimization of protease from poultry associated Bacillus licheniformis
}

\author{
Ameer Khusro \\ Department of Plant Biology and Biotechnology, Nungambakkam, Chennai, India.
}

\begin{tabular}{|c|c|}
\hline ARTICLE INFO & ABSTRACT \\
\hline Article history: & \multirow{8}{*}{$\begin{array}{l}\text { Bacteria were isolated from poultry farm of Guduvanchery, Tamil Nadu, India and exhibited variable protease } \\
\text { activity on skim milk agar plates. Of } 10 \text { bacterial isolates screened, Bacillus licheniformis strain } 018 \text { was } \\
\text { observed as a hyperprotease producer and it was further characterized using biochemical and molecular tools. } \\
\text { Protease production from the isolate was enhanced by optimizing the culture conditions using One Factor at A } \\
\text { Time (OFAT) method. The bacteria exhibited its optimal enzyme activity at pH- } 9.0 \text {, temperature- } 35^{\circ} \mathrm{C} \text {, } \\
\text { agitation speed- } 130 \mathrm{rpm} \text {, incubation time- } 24 \mathrm{~h} \text {, carbon source- casein and nitrogen source- yeast extract. On the } \\
\text { other hand, the crude proteases were found to be significantly active and stable at broad range of pH }(5.0-9.0) \text { and } \\
\text { temperature }\left(30-60^{\circ} \mathrm{C}\right) \text {. To the best of my knowledge this is the first report on the production and enhancement of } \\
\text { alkaline protease from poultry farm isolate using OFAT method. Stability of the enzyme at high temperature and } \\
\mathrm{pH} \text { can be explored for varied industrial applications. }\end{array}$} \\
\hline Rece & \\
\hline Revi & \\
\hline Acce & \\
\hline Available online: & \\
\hline & \\
\hline & \\
\hline licheniformis, OFAT, Poultry & \\
\hline
\end{tabular}

\section{INTRODUCTION}

Proteases are one of the most important classes of enzymes for biotechnological interest that account for $60 \%$ of total enzyme market. Among various types of proteases, alkaline proteases have extensive applications in industries like laundry detergents, pharmaceutical, food industry, leather processing and proteinaceous waste bioremediation because of their high proteolytic activity and stability under alkaline conditions (Bayoudh et al., 2000). Proteases from microbial sources are preferred over the enzymes from plants and animals. The majority of commercial alkaline proteases are produced by bacteria, especially from Bacillus sp (Jellouli et al., 2009). Extracellular thermoalkaline bacterial proteases are important for the hydrolysis of waste proteins and enable the bacteria to absorb and utilize hydrolytic products (Srinivasan et al., 2009; Habib et al., 2012) by growing easily under harsh conditions. A number of Bacillus derived alkaline proteases have been purified and characterized because of their significant proteolytic activity, stability, broad substrate specificity, short period of fermentation,

\footnotetext{
* Corresponding Author

Ameer Khusro, Department of Plant Biology and Biotechnology, Nungambakkam, Chennai, India. Email: armankhan0301[at]gmail.com
}

simple downstream purification and low cost (Haddar et al., 2009). Fermentation medium optimization plays a critical role in enhancing the production yields of the industrially important enzymes. Optimization for enhanced production of enzyme depends upon medium components like carbon source, nitrogen sources, $\mathrm{pH}$, temperature, agitation and incubation time. The optimization of the fermentation medium by one factor at a time (OFAT) is a potential approach in order to analyze the interactive effects of various factors. In the present day scenario, proteases have a great commercial value in biotechnological applications. Although proteases have been identified from different sources for their industrial and biotechnological applications, but still the proteases exploited is very limited to meet all the essentials because the available enzymes could not resist the drastic changes in environmental conditions that is equivalent to industrial demands. Thus, new promising bacterial strains that could survive under harsh environmental conditions could be isolated from diverse sources to enhance the yield of such enzymes. As there are very few research activities on protease production from poultry farm bacteria, hence considering the industrial importance of proteases, the present study was investigated to isolate a new Bacillus strain from poultry farm for protease production and to identify the isolate efficient for maximum protease production at different parameters using OFAT method. 


\section{MATERIALS AND METHOD}

\section{Sample collection}

Poultry faeces soil sample was collected from poultry farm of Guduvanchery, Tamil Nadu (India) in sterile container. Faeces soils were brought to the laboratory in aseptic condition for further analysis.

\section{Screening of bacteria for extracellular protease production}

The collected sample was serially diluted and streaked on sterilized skim milk agar plates. The plates were incubated for $24 \mathrm{~h}$ at $37{ }^{\circ} \mathrm{C}$ and protease producers were selected by observation of zone of hydrolysis around the colonies. Only the hyperprotease producing isolate was selected for further optimization process.

\section{Organism identification}

The isolate showing potential protease production was characterized by cultural, morphological and biochemical analysis following standard procedures according to the Bergey's Manual of Systemic Bacteriology (Sneath, 1994).

\section{Genomic DNA isolation}

Two $\mathrm{ml}$ of hyperprotease producing bacterial culture was centrifuged at $6000 \mathrm{rpm}$ for $5 \mathrm{~min}$. The supernatant was discarded. One $\mathrm{ml}$ of UniFlex ${ }^{\mathrm{TM}}$ Buffer 1 and $10 \mu \mathrm{l}$ of RNase were added to the pellet obtained. Mixed well by pipetting and incubated for 30 min at $37^{\circ} \mathrm{C}$ in a water bath. To the lysed samples $1 \mathrm{ml}$ of $1: 1$ phenol:chloroform were added and mixed well. The sample was centrifuged at $10,000 \mathrm{rpm}$ for $15 \mathrm{~min}$ at room temperature. The aqueous layers were separated in a fresh $1.5 \mathrm{ml}$ vial. To the aqueous layer $1 \mathrm{ml}$ of UniFlex ${ }^{\mathrm{TM}}$ Buffer 2 were added and mixed well by pipetting. The mixture was centrifuged at $12,000 \mathrm{rpm}$ for 15 min at room temperature. The supernatant was discarded. To the pellet $500 \mu \mathrm{l}$ of $70 \%$ ethanol were mixed. Again it was centrifuged at $10,000 \mathrm{rpm}$ for $10 \mathrm{~min}$ at $4^{\circ} \mathrm{C}$. The supernatant was discarded. The pellet was air dried for about 10-15 min till the ethanol evaporates. The pellet was resuspended in 50-100 $\mu \mathrm{l}$ of UniFlex ${ }^{\mathrm{TM}}$ Elution Buffer. DNA was stored at $-20^{\circ} \mathrm{C}$.

\section{PCR amplification and sequence of 16S rRNA}

The 16S ribosomal RNA was amplified by using the PCR (ependorfep.Gradient) with Taq DNA polymerase and universal primers. The conditions for thermal cycling were as follows: denaturation of the target $\mathrm{DNA}$ at $94^{\circ} \mathrm{C}$ for $4 \mathrm{~min}$ followed by 30 cycles at $94^{\circ} \mathrm{C}$ for $1 \mathrm{~min}$, primer annealing at $52^{\circ} \mathrm{C}$ for $1 \mathrm{~min}$ and primer extension at $72^{\circ} \mathrm{C}$ for $1 \mathrm{~min}$. At the end of the cycling, the reaction mixture was held at $72^{\circ} \mathrm{C}$ for $10 \mathrm{~min}$ and then cooled to $4{ }^{\circ} \mathrm{C}$. PCR amplification was detected by agarose gel electrophoresis and visualized by alpha image gel doc after ethidium bromide staining.

\section{Sequencing of PCR product and BLAST search}

The PCR product obtained was sequenced by an automated sequencer (Genetic Analyzer 3130, Applied
Biosystems, and USA). The same primers were also used for sequencing.

The sequence was compared for similarity with the reference species of bacteria contained in genomic database banks, using the NCBI BLAST available at http:// www.ncbi-nlmnih.gov/. The sequences were submitted to GenBank and the following accession number was assigned for the isolate; Bacillus licheniformis strain 018 - KC342225

\section{Protease production}

Extracellular protease production was carried out using basal media - Glucose, 0.5\% (w/v); Peptone, 0.75\% (w/v); Salt solution- $5 \%(\mathrm{v} / \mathrm{v}) \quad\left\{\left(\mathrm{MgSO}_{4} \cdot 7 \mathrm{H}_{2} \mathrm{O}, 0.5 \%(\mathrm{w} / \mathrm{v}) ; \mathrm{KH}_{2} \mathrm{PO}_{4} 0.5 \%\right.\right.$ (w/v) ; and $\mathrm{FeSO}_{4} .7 \mathrm{H}_{2} \mathrm{O}, 0.01 \%$ (w/v) at $160 \mathrm{rpm}$. The culture medium was harvested and was subjected to centrifugation at $8,000 \mathrm{rpm}$ for $10 \mathrm{~min}$ to obtain crude enzyme source. The isolate was taken for further optimization studies to enhance the protease production using OFAT method.

\section{Extracellular Protease assay}

One $\mathrm{ml}$ of enzyme was added to $2 \mathrm{ml}$ of casein $(1 \% \mathrm{w} / \mathrm{v}$ in $0.1 \mathrm{~N}$ Glycine $-\mathrm{NaOH}$ buffer $\mathrm{pH} 10$ ) and the mixture was incubated for $15 \mathrm{~min}$ at $60^{\circ} \mathrm{C}$. The reaction was terminated by adding $3 \mathrm{ml}$ of $10 \%$ trichloroacetic acid reagent and then centrifuged for $15 \mathrm{~min}$ at $10,000 \mathrm{rpm}$.

Then $1 \mathrm{ml}$ of filtrate was mixed with $5 \mathrm{ml}$ of alkaline copper reagent and after $15 \mathrm{~min} 0.5 \mathrm{ml}$ of Folin-ciocalteau reagent was added. After $30 \mathrm{~min}$ of incubation the absorbance was read at $700 \mathrm{~nm}$. Similarly blank was carried out by replacing enzyme with distilled water.

One unit enzyme activity is defined as the amount of enzyme that releases $1 \mu \mathrm{g}$ of tyrosine per $\mathrm{ml}$ per min under the assay conditions. Tyrosine at the concentration of 50-250 $\mu \mathrm{g}$ was used as standard.

\section{Estimation of total soluble protein}

Estimation of total extracellular protein was performed through Bradford test (Bradford, 1976). Bradford method is a simple and rapid method to estimate the protein content in a sample based on the ability of protein to bind with the dye Coomassie Brilliant Blue G250.

The unbound dye has an absorption maxima of $495 \mathrm{~nm}$, on binding with the protein, the absorption maxima becomes 595 $\mathrm{nm}$. Thus from the absorbance at $595 \mathrm{~nm}$, the protein in the sample solution can be estimated. Bovine serum albumin (BSA) was used as standard. Hundred microliter of bacterial supernatant was pipetted out into test tubes. Volume of the tubes was made up to 1 $\mathrm{ml}$ using sterilized distilled water.

Five millilitre of the Bradford reagent were added to all the tubes and mixed thoroughly. One $\mathrm{ml}$ of distilled water with 5 $\mathrm{ml}$ of Bradford reagent was used as blank. Absorbance at $595 \mathrm{~nm}$ was recorded against blank. Protein content per millilitre of test samples was determined against the standard curve. 
Optimization of process parameters by OFAT (One factor at a time) method and growth kinetics of bacteria

In order to study the growth kinetics and protease activity of bacteria, the organism was grown in the liquid media. Growth was estimated by measuring optical density of culture broth at various parameters. Using OFAT method, the production media was optimized with various fermentation parameters like $\mathrm{pH}$, temperature, agitation, incubation period, additional carbon sources and nitrogen sources after working out a series of experiments for the bacterial strain. Effect of $\mathrm{pH}$ on protease activity was assessed by cultivating the isolate (1\% inoculum) in the production media of varied $\mathrm{pH}$ ranging from 5-10. The influence of $\mathrm{pH}$ on protease activity over casein was investigated in $100 \mathrm{mM}$ phosphate buffer with desired $\mathrm{pH}$. The influence of different fermentation temperature such as $30^{\circ} \mathrm{C}, 35^{\circ} \mathrm{C}, 40^{\circ} \mathrm{C}$, $45^{\circ} \mathrm{C}$ and $50^{\circ} \mathrm{C}$ on protease activity was evaluated under optimized $\mathrm{pH}$ (using $100 \mathrm{mM}$ phosphate buffer) of media for the isolate (1\% inoculum).

The fermentation medium with optimized $\mathrm{pH}$ was incubated at optimized temperature in order to study enzyme activity at different agitation rate. The fermentation was carried out at varying agitation speed such as $120 \mathrm{rpm}, 130 \mathrm{rpm}, 140 \mathrm{rpm}$, $150 \mathrm{rpm}$ and $160 \mathrm{rpm}$ in an orbital shaking incubator. The bacterial inoculum $(1 \%)$ was added to $50 \mathrm{~mL}$ of fermentation medium in $250 \mathrm{~mL}$ of Erlenmeyer flasks.

The flask was incubated at optimized $\mathrm{pH}$, temperature and agitation for 12-96 h. The effect of various carbon and nitrogen sources on the extracellular protease production was studied at optimized parameters.

Approximately 1\% (w/v) of carbon sources (Glucose, Casein, Xylose, Sucrose, Lactose and Mannose) and nitrogen sources (Peptone-Pep, Yeast extract-YE, Beef extract-BE, Tryptone-Tryp, $\mathrm{KNO}_{3}$, Ammonium sulphate- Asp and Ammonium chloride- $\mathrm{ACl}$ )) were added separately to the production media. After $24 \mathrm{~h}$ of incubation, cultures were centrifuged at $6000 \mathrm{~g}$ for $10 \mathrm{~min}$ at $4^{\circ} \mathrm{C}$ and the supernatants were collected. The extracellular protease activity was estimated as described earlier.

\section{Estimation of biomass (Analytical study)}

Two millilitre sample was collected in a pre-weighed eppendorf tube and centrifuged at $8000 \mathrm{rpm}$ for $10 \mathrm{~min}$. Supernatant was discarded and the pellet was washed thrice with sterile distilled water, followed by drying the pellets at $95^{\circ} \mathrm{C}$ till constant weight and expressed in dry cell weight $(\mathrm{mg} / \mathrm{mL})$.

\section{Partial characterization of crude protease}

\section{Temperature stability}

The temperature stability of the enzyme was studied by using crude enzyme. To evaluate thermal stability, the enzyme solution was incubated at temperatures of $30-70^{\circ} \mathrm{C}$ for up to $4 \mathrm{~h}$. The relative enzyme activity was recorded at $1 \mathrm{~h}$ interval during 4 $\mathrm{h}$ incubation. The enzyme activity was determined as described earlier. The relative activity was estimated taking original activity as $100 \%$.

\section{pH stability}

$\mathrm{pH}$ stability was measured by incubating the enzyme at pH 5 to 10 in different buffers $(0.1 \mathrm{M})$ such as Sodium phosphate (pH 5.0 to 7.0), Tris- $\mathrm{HCl}(\mathrm{pH} 8.0,9.0)$ and Carbonate-bicarbonate ( $\mathrm{pH}$ 10.0). To evaluate the stability of the enzyme at each $\mathrm{pH}$, the crude enzyme was incubated into the respective buffer over a $\mathrm{pH}$ range of $5.0-10.0$ for up to $4 \mathrm{~h}$ at optimum temperature. The relative enzyme activity was determined at $1 \mathrm{~h}$ interval during the $4 \mathrm{~h}$ period of incubation. The enzyme activity was determined as described earlier. The relative activity was estimated taking original activity as $100 \%$.

\section{Antibiotic susceptibility}

The growth behaviour of the isolate was studied in the presence of a range of antibiotics. The antibiotics used in this study were Ampicillin (AMP- $10 \mu \mathrm{g}$ ), Kanamycin (K- $30 \mu \mathrm{g}$ ), Nalidixic acid (NA- $30 \mu \mathrm{g})$, Streptomycin (S- $10 \mu \mathrm{g}$ ), Cephotaxime (CTX- 30 $\mu \mathrm{g})$ and Penicillin (P- $10 \mu \mathrm{g})$.

\section{Phylogenetic tree analysis}

Phylogenetic relationship of the isolate with other Bacillus species was inferred from phylogenetic comparison of the 16S rRNA sequences.

The partial 16S rRNA sequences were retrieved on NCBI server using BLAST tool. Sequences similar to isolate sequences were downloaded in FASTA format from NCBI server. Phylogenetic tree was inferred using the Neighbor-Joining (NJ) algorithm in Molecular Evolution Genetic Analysis (MEGA) software version 4.0 (Tamura et al., 2007). The evolutionary history was inferred using $\mathrm{NJ}$ method.

\section{Statistical analysis}

All the analytical experiments were conducted in triplicates and data presented is mean \pm SD.

\section{RESULTS}

\section{Isolation and screening of protease producing bacteria}

Ten bacteria were isolated from faeces soil samples of poultry farm, collected from Guduvanchery. These isolates were further screened for extracellular protease production. Of 10 isolates, 1 showed the production of hyperprotease on skim milk agar plate (Figure not shown). This protease positive isolate was further selected for cultural, morphological and biochemical characteristics.

\section{Morphological characterization and bacterial identification}

The cultural, morphological and biochemical characteristics of the isolate was studied (Table 1). The bacterial culture showed white and spreading type colonies. The microscopic observation showed the morphology of culture as rod shaped with endospore. The isolate was identified as Bacillus sp. based on the taxonomical characteristics. Genomic DNA of the isolate was visualized under UV. In the present study, 16S rRNA gene sequencing of the isolate was investigated. The isolate was 
identified as Bacillus licheniformis strain 018 (Accession number $\mathrm{KC} 342225$ ) by comparing the similarity with the reference species of bacteria contained in genomic database banks, using the NCBI BLAST.

Table 1: Morphological and Biochemical characteristics.

\begin{tabular}{ll}
\hline Tests & strain $\mathbf{0 1 8}$ \\
\hline Surface & Smooth \\
Colony colour & White \\
Opacity & Opaque \\
Gram reaction & Gram $(+)$ \\
Cell shape & Rod \\
Endospore & + \\
Motility & + \\
Glucose test & + \\
Lactose test & + \\
Mannitol test & + \\
Starch hydrolysis & + \\
Tween 80 & - \\
Casein & + \\
Indole & - \\
Methyl Red & + \\
Voges Proskauer & + \\
Citrate utilization & + \\
Urease test & - \\
Catalase test & + \\
Oxidase test & + \\
Aerobic growth & + \\
\hline ' = Positive; ' $=$ Negative & +
\end{tabular}

\section{Effect of $\mathrm{pH}$ on protease activity}

Protease activity was markedly affected by change in $\mathrm{pH}$. $\mathrm{pH}$ played a major role in the secretion and production of protease by the isolate (Figure 1a). During optimization study $\mathrm{pH}$ was changed from 5 to 10 for the isolate. Maximum protease activity of $61.891 \mathrm{U} / \mathrm{mL}$ was estimated by strain 018 at alkaline $\mathrm{pH}(\mathrm{pH} 9)$.

\section{Effect of temperature on protease activity}

The fermentation temperature also plays a very important role in the production of protease by the isolate. Figure $1 \mathrm{~b}$ shows the extracellular protease activity of the isolate at different temperatures under optimized $\mathrm{pH}$ of the isolate. Maximum enzyme activity of $60.552 \mathrm{U} / \mathrm{mL}$ was observed by the isolate at $35^{\circ} \mathrm{C}$.

\section{Effect of agitation speed on protease activity}

The influence of varying agitation for protease activity was evaluated in Figure 1c. Protease activity for strain 018 (62.91 $\mathrm{U} / \mathrm{mL}$ ) was found to be maximum at $130 \mathrm{rpm}$. The agitation speed lower and higher than $130 \mathrm{rpm}$ affected the enzyme activity for the isolate.

\section{Effect of incubation time on protease activity}

Time period plays a very critical role in the protease production. In the present investigation protease activity was determined from 12- $96 \mathrm{~h}$. The obtained results indicated that the highest yield of extracellular protease was $65.86 \mathrm{U} / \mathrm{mL}$ after $24 \mathrm{~h}$ of incubation. After $24 \mathrm{~h}$, the protease production was drastically decreased up to $96 \mathrm{~h}$ in a constant manner (Figure 1d).

\section{Effect of carbon and nitrogen sources}

The effect of various carbon and nitrogen sources on extracellular protease production is shown in Figure 1e and $1 \mathrm{f}$ respectively. The isolate showed enhancement in the enzyme production when grown in the media supplemented with $1 \%(\mathrm{w} / \mathrm{v})$ casein and yeast extract.

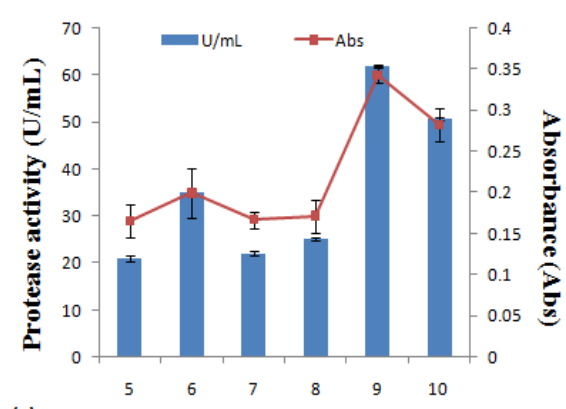

(a)

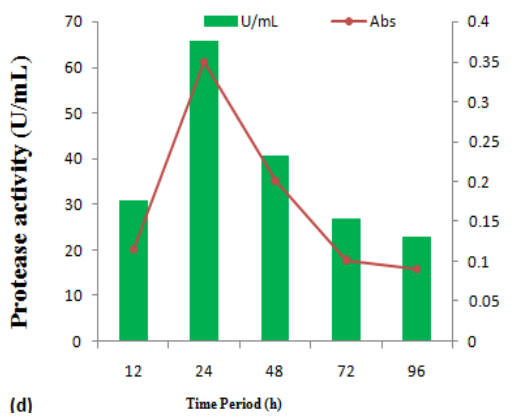

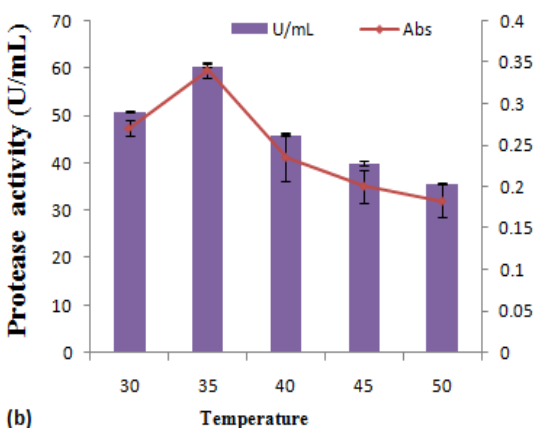

(b)

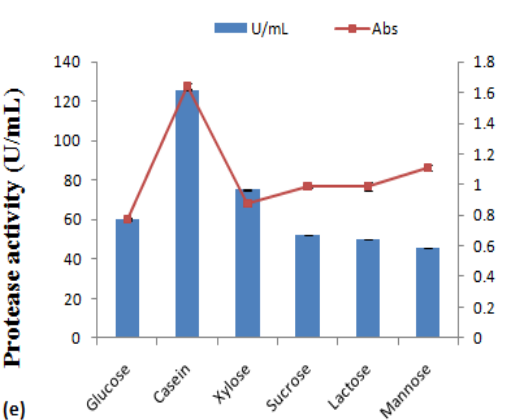

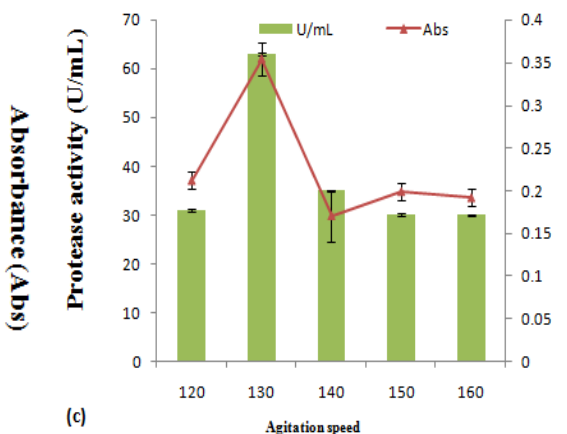

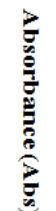

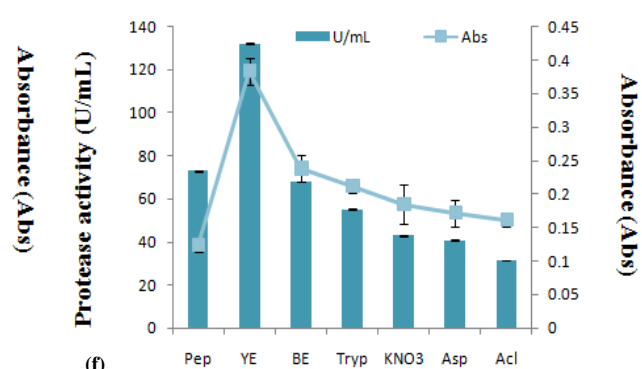

(f)

Fig. 1: Effect of various process parameters on protease production. Bacillus licheniformis strain 018 was showing maximum protease activity at pH 9 (a), at $35^{\circ} \mathrm{C} \mathrm{(b),} \mathrm{at} 130 \mathrm{rpm}$ (c), after $24 \mathrm{~h}$ of incubation (d), in the presence of casein as sole carbon source (e) and in the presence of yeast extract as sole nitrogen source (f). 
Table 2: Effect of culture conditions for extracellular protease activity and biomass production from Bacillus licheniformis strain 018 in shake-flask cultivations.

\begin{tabular}{|c|c|c|c|c|}
\hline Culture conditions & $\begin{array}{c}\text { Protease activity }(\mathrm{U} / \mathrm{mL}) \\
(\text { Mean } \pm \text { SD) }\end{array}$ & Relative activity (\%) & $\begin{array}{c}\text { Total soluble protein }(\mathrm{mg} / \mathrm{mL}) \\
(\text { Mean } \pm \text { SD })\end{array}$ & $\begin{array}{l}\text { Dry weight of biomass } \\
(\mathrm{mg} / \mathrm{mL})(\text { Mean } \pm \text { SD })\end{array}$ \\
\hline \multicolumn{5}{|c|}{ Bacillus licheniformis strain 018} \\
\hline \multicolumn{5}{|l|}{ pH } \\
\hline 5 & $21.012 \pm 0.51$ & 33.94 & $0.321 \pm 0.02$ & $0.4 \pm 0.02$ \\
\hline 6 & $35.031 \pm 0.35$ & 56.59 & $0.467 \pm 0.01$ & $2.0 \pm 0.01$ \\
\hline 7 & $22.036 \pm 0.51$ & 35.6 & $0.359 \pm 0.02$ & $0.63 \pm 0.01$ \\
\hline 8 & $25.191 \pm 0.42$ & 40.7 & $0.413 \pm 0.01$ & $0.65 \pm 0.03$ \\
\hline 9 & $61.891 \pm 0.35$ & 100 & $0.458 \pm 0.03$ & $1.2 \pm 0.01$ \\
\hline 10 & $50.781 \pm 0.26$ & 82.04 & $0.296 \pm 0.021$ & $1.3 \pm 0.01$ \\
\hline \multicolumn{5}{|l|}{ Temperature $\left({ }^{\circ} \mathrm{C}\right)$} \\
\hline 30 & $50.782 \pm 0.12$ & 83.86 & $0.15 \pm 0.01$ & $1.2 \pm 0.02$ \\
\hline 35 & $60.552 \pm 0.33$ & 100 & $0.304 \pm 0.02$ & $1.8 \pm 0.02$ \\
\hline 40 & $45.862 \pm 0.21$ & 75.74 & $0.589 \pm 0.04$ & $1.6 \pm 0.01$ \\
\hline 45 & $40.001 \pm 0.35$ & 66.06 & $0.411 \pm 0.01$ & $1.5 \pm 0.02$ \\
\hline 50 & $35.782 \pm 0.21$ & 59.09 & $0.4 \pm 0.01$ & $1.5 \pm 0.01$ \\
\hline \multicolumn{5}{|l|}{ Agitation speed (rpm) } \\
\hline 120 & $31.021 \pm 0.22$ & 49.31 & $0.216 \pm 0.03$ & $1.3 \pm 0.03$ \\
\hline 130 & $62.91 \pm 0.35$ & 100 & $0.477 \pm 0.04$ & $2.0 \pm 0.01$ \\
\hline 140 & $35.001 \pm 0.13$ & 55.63 & 0.3110 .01 & $1.3 \pm 0.01$ \\
\hline 150 & $30.10 \pm 0.24$ & 47.84 & $0.211 \pm 0.01$ & $0.6 \pm 0.02$ \\
\hline 160 & $30.08 \pm 0.11$ & 47.63 & $0.21 \pm 0.02$ & $0.7 \pm 0.01$ \\
\hline \multicolumn{5}{|l|}{ Incubation time (h) } \\
\hline 12 & $30.97 \pm 0.23$ & 47.02 & $0.112 \pm 0.03$ & $0.8 \pm 0.02$ \\
\hline 24 & $65.86 \pm 0.12$ & 100 & $0.452 \pm 0.02$ & $2.2 \pm 0.01$ \\
\hline 48 & $40.605 \pm 0.21$ & 61.66 & $0.381 \pm 0.01$ & $1.8 \pm 0.01$ \\
\hline 72 & $26.896 \pm 0.31$ & 40.83 & $0.211 \pm 0.01$ & $1.9 \pm 0.03$ \\
\hline 96 & $22.811 \pm 0.33$ & 34.63 & $0.0677 \pm 0.02$ & $1.6 \pm 0.02$ \\
\hline \multicolumn{5}{|l|}{ Carbon source } \\
\hline Glucose & $60.523 \pm 0.31$ & 47.71 & $0.321 \pm 0.02$ & $1.4 \pm 0.01$ \\
\hline Casein & $125.752 \pm 0.35$ & 100 & $0.432 \pm 0.01$ & $2.5 \pm 0.01$ \\
\hline Xylose & $75.123 \pm 0.25$ & 59.73 & $0.311 \pm 0.02$ & $1.9 \pm 0.02$ \\
\hline Sucrose & $52.321 \pm 0.28$ & 41.6 & $0.221 \pm 0.01$ & $1.6 \pm 0.02$ \\
\hline Lactose & $50.023 \pm 0.11$ & 39.77 & $0.178 \pm 0.01$ & $1.8 \pm 0.01$ \\
\hline Mannose & $45.541 \pm 0.21$ & 36.21 & $0.213 \pm 0.03$ & $1.1 \pm 0.02$ \\
\hline \multicolumn{5}{|l|}{ Nitrogen source } \\
\hline Peptone & $72.976 \pm 0.22$ & 55.15 & $0.115 \pm 0.02$ & $0.8 \pm 0.02$ \\
\hline Yeast extract & $132.321 \pm 0.11$ & 100 & $0.338 \pm 0.03$ & $2.7 \pm 0.02$ \\
\hline Beef extract & $68 \pm 0.17$ & 51.39 & $0.221 \pm 0.01$ & $2.0 \pm 0.01$ \\
\hline Tryptone & $55.231 \pm 0.16$ & 41.74 & $0.117 \pm 0.01$ & $1.3 \pm 0.03$ \\
\hline $\mathrm{KNO}_{3}$ & $43.001 \pm 0.12$ & 32.49 & $0.222 \pm 0.03$ & $1.6 \pm 0.01$ \\
\hline Ammonium sulphate & $40.875 \pm 0.15$ & 30.89 & $0.117 \pm 0.01$ & $1.1 \pm 0.02$ \\
\hline Ammonium chloride & $31.31 \pm 0.1$ & 23.66 & $0.224 \pm 0.02$ & $0.6 \pm 0.035$ \\
\hline
\end{tabular}

\section{Biomass estimation}

Dry cell weight $(\mathrm{DCW}, \mathrm{mg} / \mathrm{mL})$ was analyzed for the isolate at different parameters $(\mathrm{pH}$, temperature, agitation speed, incubation time, carbon and nitrogen sources). The results indicate good biomass production for protease production. The biomass production was more for the isolate at optimum condition of selected parameters (Table 2).

\section{Effect of temperature and $\mathrm{pH}$ on the stability of crude alkaline protease}

Stability is one of the most important factors in studying characteristics of enzyme. Crude protease obtained from strain 018 was more stable till $60^{\circ} \mathrm{C}$ for $4 \mathrm{~h}$ of incubation and retained upto $67 \%$ of the activity. The enzyme stability was reduced significantly above $60{ }^{\circ} \mathrm{C}$ (Figure $2 \mathrm{a}$ ).
The effect of $\mathrm{pH}$ on stability of protease from the isolate is shown in Figure $2 \mathrm{~b}$. The crude protease obtained from strain 018 was stable at a wide range of $\mathrm{pH}$ from 5.0 to 9.0. The isolate was found stable upto $\mathrm{pH} 9.0$ for $4 \mathrm{~h}$ of incubation. About $60 \%$ of activity was retained by strain 018 at $\mathrm{pH} 9.0$.

\section{Antibiotic susceptibility test and Phylogenetic tree of the isolate}

The isolate was found to be susceptible to all the antibiotics tested here (Data not shown). A Neighbor- joining tree of isolate's 16S rRNA sequences, including different strains of Bacillus species, clustered all the isolates belonging to the previously identified species to the corresponding species (Figure 3). 

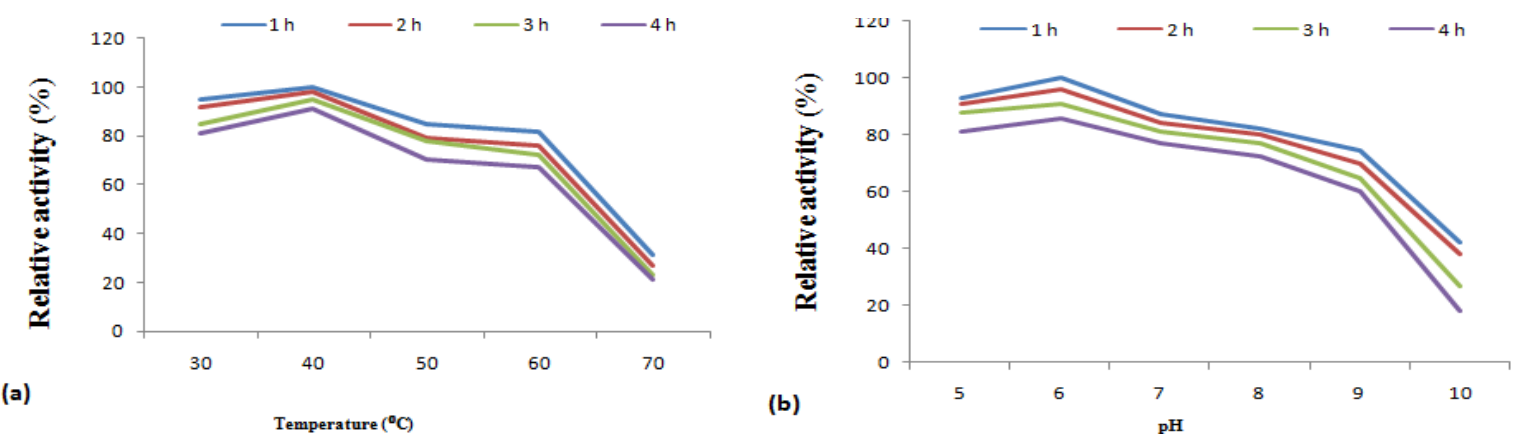

Fig. 2: (a) Effect of temperature on stability of crude protease. The crude protease obtained from the isolate was found to be thermo-stable upto $60^{\circ} \mathrm{C}$ for $4 \mathrm{~h}$ of incubation. Further, there was drastic decrease in the stability of the enzyme as the temperature rises up to $70^{\circ} \mathrm{C}$. (b) Effect of $\mathrm{pH}$ on stability of crude protease. The crude enzyme obtained from strain 018 was showing maximum stability up to $\mathrm{pH} 9$ for $4 \mathrm{~h}$ of incubation. As the $\mathrm{pH}$ was increased further, the stability was lost drastically.

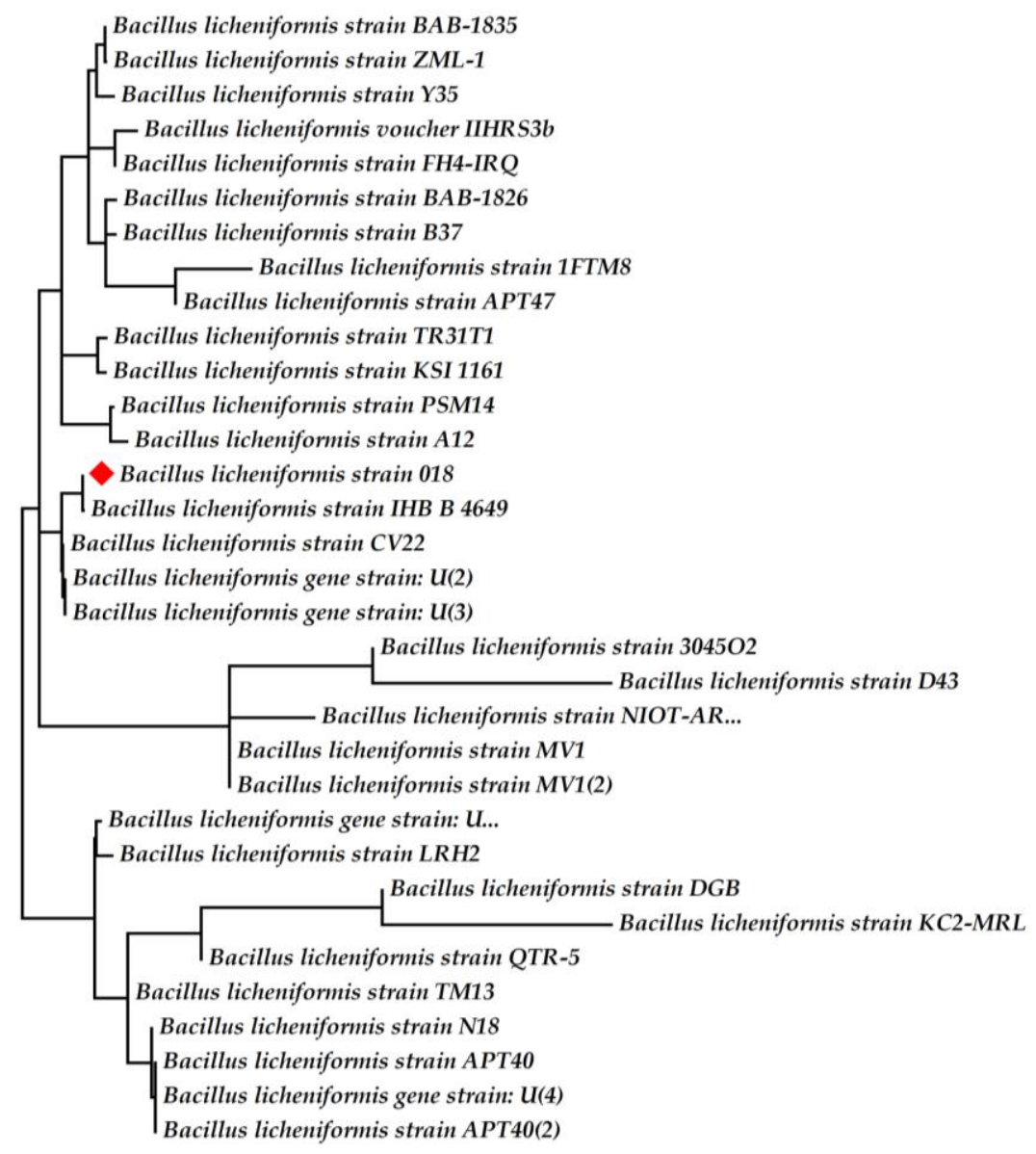

Fig. 3: Phylogenetic tree based on a comparison of the $16 \mathrm{~S}$ ribosomal RNA sequences of Bacillus isolate and some of their closest phylogenetic relatives. The isolate characterized in the present study is indicated in red bullet.

\section{DISCUSSION}

Members of the genus Bacillus produce large variety of extracellular enzymes, of which proteases play an important role at industrial scale. In the primary step of this investigation, the hyperprotease producing Bacillus $\mathrm{sp}$. was isolated from the collected sample by screening procedure on skim milk agar plate.

The culture conditions were found to have profound influence on extracellular protease production (Table 2). In the present study the changes in $\mathrm{pH}$ from 5-10 caused change in the protease activity of the isolate. $B$. licheniformis strain 018 was showing maximum enzyme activity at $\mathrm{pH}$ 9. The study strongly favours the finding of Kumar et al. (1999), Khusro (2015) and Pastor et al. (2001) who demonstrated that Bacillus sp. had shown maximum protease production at high $\mathrm{pH}$. Similar results were also obtained by Almas et al. (2009). It is clear from the present investigation that strain 018 can be used at large scale in food, tannery and detergent industries because of its alkaline tolerant nature. $\mathrm{pH}$ played an important role in the production of extracellular protease by each isolate. This is because substrate 
binding and catalysis are often dependent on charge distribution on both substrate and in particular enzyme molecules. $\mathrm{pH}$ markedly affects the metabolic pathways of microorganisms. Changes in the external $\mathrm{pH}$ alter the ionization of nutrient molecules and reduce their availability to the microorganisms thus lowering their overall metabolic activity (Willey et al., 2008).

Temperature had profound effect on protease production. The isolate showed maximum protease activity at $35^{\circ} \mathrm{C}$. Enzyme activity was $100 \%$ at $35^{\circ} \mathrm{C}$ for strain 018 . The finding of this present study supports the application of the isolate in waste water treatment. The isolate can be used in the bioremediation of wastewater treatment. However our study was against the finding of Khan et al. (2011) who found that protease produced by Bacillus sp. gave the best activity at $50^{\circ} \mathrm{C}$. The variations among our findings and the previous reports may be because of the source of the isolation and types of bacterial strain. In order to convert casein substrate into product, enzyme must collide with and bind to the substrate at the active site. Increasing or decreasing the temperature of a system will increase or decrease the number of collisions of enzyme and substrate per unit time. Thus, within limits, the rate of the reaction will change. For the mesophilic bacteria, as the temperature of the system increases, it causes thermal denaturation of the protein and enzymes. Thus too much heat can cause the rate of an enzyme catalyzed reaction to decrease because the enzyme or substrate becomes denatured and inactive.

Aeration is one of the effective factors for the improvement of aerobic fermentation. The present experiments were carried out under the variation of shaking speed ranging from 120-160 rpm in order to optimize the aerobic condition in shake flask cultivation. According to the present context results, maximum protease activity by strain 018 was observed at $130 \mathrm{rpm}$. The reason behind this may be the uniform distribution of nutrient and supplied oxygen for the cultivation of this particular strain in the fermentation medium. Incubation period is one of the most important parameter in metabolic activity and growth of bacteria. The results obtained in this study indicated that highest yield of protease by the isolate was obtained at $24 \mathrm{~h}$ of incubation. A decline in protease activity afterwards was probably due to depletion of nutrients in the fermentation medium of the microorganism, causing stressed and unfavourable conditions for the bacteria resulting in reduction of enzyme activity. Our reports were against the findings of Khan et al. (2011) who demonstrated maximum protease activity by Bacillus sp. at $36 \mathrm{~h}$ of incubation. Findings of the corresponding experiments revealed that the time course of enzyme activity varies with the source of isolation, strains used, genetic makeup of strains and cultivation conditions. Incubation beyond the optimum time course was generally accompanied by a decrease in the growth rate and enzyme productivity, which gradually declined after $24 \mathrm{~h}$ of incubation. The decreased activity in the later phase of growth was probably due to catabolite repression by readily metabolizable substrate glucose (Lin et al., 1998). Carbon is the essential element for the growth and metabolism of bacteria. The enzyme production is stimulated in the presence of various carbon sources. In the present context, optimal level of extracellular protease from the isolate was recorded when casein was used as a sole carbon source. Lakshmi et al. (2014) recorded maximum protease production from Bacillus sp. in the presence of molasses. Various organic and inorganic nitrogen sources were tested to estimate the maximum protease production from the isolate. Yeast extract was found to be the best nitrogen source for the isolate in order to achieve maximum production of protease. The present investigation supports the finding of Vanitha et al. (2014) who demonstrated yeast extract as a potential nitrogen source for protease production. Yeast extract has been reported to play an important role in enzyme production due to the presence of essential elements and growth factors (Porsuk et al., 2013). In the present investigation crude protease obtained from strain 018 was more stable up to $60^{\circ} \mathrm{C}$ for $4 \mathrm{~h}$ of incubation and retained upto $67 \%$ of the activity. Our study was against the finding of Abusham et al. (2009) who demonstrated that protease obtained from bacteria was more stable at $50^{\circ} \mathrm{C}$. Thus, the results concluded that the crude enzyme is moderately temperature stable. Significant enzyme stability at higher temperatures would be important for several industrial processes. The industrial importance of an enzyme will be more when the effect of temperature input on its optimal activity is less.

The most desirable characteristic of the isolate of present investigation was steady stability at alkaline $\mathrm{pH}$. The crude protease obtained from the isolate showed stability at a wide range of $\mathrm{pH}$ from 5.0 to 9.0. The outcome of the present study is similar to the finding of Almas et al. (2009) who demonstrated stability of protease at $\mathrm{pH}$ 9. Many of the microorganisms have been found to produce protease with $\mathrm{pH}$ optima near neutral region but with high stability in alkaline conditions. Stability at alkaline $\mathrm{pH}$ values may be due to charged amino acid residues. The enzymes stable in alkaline conditions were characterized by a decreased number of acidic residues and an increased number of arginines (Hakulinen et al., 2003). The isolate of the present context could be a good source for biotechnological applications at industrial scale because of the alkali stability nature of protease. 16S rRNA gene sequences to study bacterial phylogeny and taxonomy have been by far the most common molecular marker. $16 \mathrm{~S}$ ribosomal RNA-based molecular identification could achieve identification because of the presence of species-specific variable regions. This molecular approach has been extensively used for bacterial phylogeny, leading to the establishment of large public-domain databases and its application to bacterial identification, including that of environmental and clinical uncultured microorganisms, unique or unusual isolates and collections of phenotypically identified isolates (Drancourt et al., 2000).

\section{CONCLUSION}

The results obtained from the present investigation indicate enhanced production of alkaline protease from Bacillus licheniformis strain 018 under optimized medium components and 
culture conditions by using traditional OFAT method. The most significant findings of this study were the ability of the isolate to produce maximum level of extracellular alkaline protease after 24 $\mathrm{h}$ of incubation, and the stability of enzyme at high temperature and $\mathrm{pH}$. The best process parameters were found to be casein as the sole carbon source and yeast extract as nitrogen source. The isolate of the present context could be a good alternative of the commercial strains in tanneries, pharmaceutical and food processing industries as biotechnological and physiological aspects due to the thermo-alkaline nature of protease obtained. Further studies are in progress in order to purify the alkaline protease from the isolate and the scaling up of the enzyme for commercial applications.

\section{REFERENCES}

Abusham RA, Rahman RNZRA, Salleh AB, Basri M. Optimization of physical factors affecting the production of thermo-stable organic solvent tolerant protease from a newly isolated halo tolerant Bacillus subtilis strain R. Microb Cell Factories. 2009; 8: 20-25.

Almas S, Hameed A, Shelly D, Mohan P. Purification and characterization of novel protease from Bacillus strain SAL 1. Afr $J$ Biotechnol. 2009; 8: 3603-3609.

Bayoudh A, Gharsallah N, Chamkha M, Dhouib A, Ammar S, Nasri M. Purification and characterization of an alkaline protease from Pseudomonas aeruginosa MN1. J Ind Microbiol Biotechnol. 2000; 24: 291-295

Bradford MM. A rapid and sensitive for the quantitation of microgram quantitites of protein utilizing the principle of protein-dye binding. Analyt Biochem. 1976; 72: 248-254.

Drancourt M, Bollet C, Carlioz A, Martelin R, Gayral JP, Raoult D. 16S Ribosomal DNA sequence analysis of a large collection of environmental and clinical unidentifiable bacterial isolates. $J$ Clin Microbiol. 2000; 38: 3623-3630

Habib SMA, Fakhruddin ANM, Begum S, Ahmed MM. Isolation and screening of thermostable extracellular alkaline protease producing bacteria from tannery effluents. $J$ Sci Res. 2012; 4: 515-522

Haddar A, Agrebi R, Bougatef A, Hmidet N, SellamiKamoun A, Nasri M. Two detergent stable alkaline serine proteases from Bacillus mojavensis A21: purification, characterization and potential application as a laundry detergent additive. Bioresour Technol. 2009; 100: 3366-3373.

Hakulinen N, Turunen O, Janis J, Leisola M, Rouvinen J. Three-dimensional structures of thermophilic $\beta-1,4$-xylanases from Chaetomium thermophilum and Nonomuraea flexuosa comparison of twelve xylanases in relation to their thermal stability. Eur J Biochem. 2003; 270: 1399-1412.
Jellouli K, Bougatef A, Manni L, Agrebi R., Siala R, Younes I, Nasri M. Molecular and biochemical characterization of an extracellular serine-protease from Vibrio metschnikovii J1. J Ind Microbiol Biotechnol. 2009; 36: 939-948

Khan MA, Ahmad N, Zafar AU, Nasir IA, Qadir MA. Isolation and screening of alkaline protease producing bacteria and physio-chemical characterization of the enzyme. Afr J Biotechnol. 2011; 10: 6203-6212

Khusro A. 2015. Statistical approach for optimization of independent variables on alkali-thermo stable protease production from Bacillus licheniformis strain BIHPUR 0104. Electronic J Biol. 2015; 11: 93-97

Kumar CG, Tiwari MP, Jany KD. Novel alkaline serine proteases from alkalophilic Bacillus spp.: purification and some properties. Process Biochem. 1999; 34: 441-449.

Lakshmi BKM, Ratna sri PV, Ambika Devi K, Hemalatha KPJ. Screening, optimization of production and partial characterization of alkaline protease from haloalkaliphilic Bacillus sp. Int J Res Eng Tech. 2014; 3: 435-443

Lin L, Chyau C, Hsu WH. Production and properties of a raw starch-degrading amylase from thermophilic and alkaliphilic Bacillus sp. TS-23. Biotechnol Appl Biochem. 1998; 28: 61-68.

Pastor MD, Lorda GS, Balatti A. Proteases production using Bacillus subtilis- 3411 and amaranth seed meal medium at different aeration rate. Braz J Microbio. 2001; 32: 6-9.

Porsuk I, Ozakin S, Bali B, Yilmaz EI. A cellulase-free, thermoactive, and alkali xylanase production by terrestrial Streptomyces sp. CA24. Turk J Biol. 2013; 37: 370-375.

Sneath PHA. 1994. Gram positive rods. Bergeys Manual of Systematic Bacteriology (ed Hensyl, W.M.) 9th edition, Philadelphia PA Williams and Wilkins. p. 2106-2111.

Srinivasan TS, Das S, Balakrishnan V, Philip R, Kannan N. Isolation and characterization of thermostable protease producing bacteria from tannery industry effluent. Recent Res Sci Technol. 2009; 1: 63-66

Tamura K, Dudley J, Nei M, Kumar S. MEGA4: Molecular Evolutionary Genetics Analysis (MEGA) software version 4.0. Mol Biol Evol. 2007; 24: 1596-1599.

Vanitha N, Rajan S, Murugesan AG. Optimization and production of alkaline protease enzyme from Bacillus subtilis 168 isolated from food industry waste. Int J Curr Microb Appl Sci. 2014; 3: 36-44

Willey JM, Sherwood LM, Woolverton CJ. 2008. Prescott, Harley and Klein's Microbiology, Singapore McGraw-Hill, p. 1088.

\section{How to cite this article:}

Ameer Khusro. One Factor at A Time based optimization of protease from poultry associated Bacillus licheniformis. J App Pharm Sci, 2016; 6 (03): 088-095. 